\title{
The general revelation of God and creational gifts as a source for bioethics
}

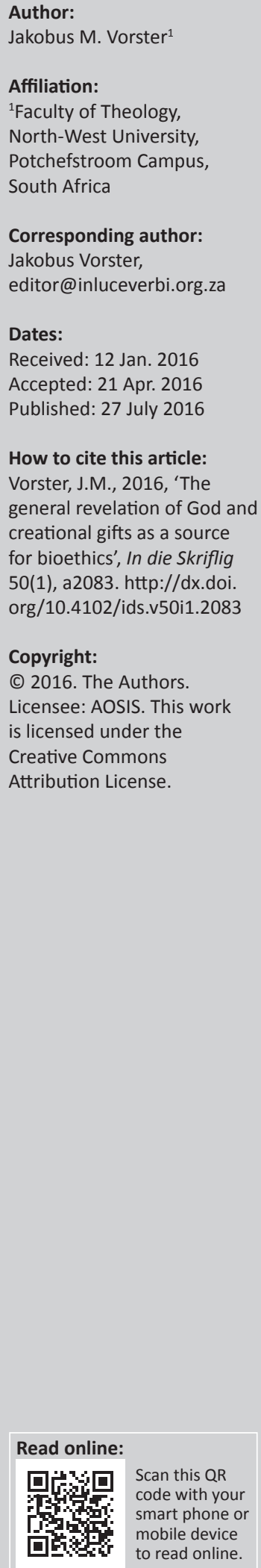

This article aims to provide a Christian-ethical foundation for the development of moral codes for bio- and ecoethics. The central theoretical argument of this contribution is that, due to the general revelation of God in nature, the Spirit of God bestows all humans with creational gifts. Seen as such the concept of natural law can be regarded, with certain conditions, as a credible and useful tool in the reformed paradigm. This article examines the concept of natural law as this idea is defined by Calvin and developed in the recent reformed tradition. Attention is paid to the criticism of Karl Barth and the view of Michael Welker and a way forward is proposed in view of the idea of God's revelation in creation, the written Word and the incarnate Word of God, and the creational gifts bestowed by God upon all humans. The article concludes that natural knowledge, based on God's revelation in creation as it is revealed by the natural sciences, provides Christian ethics with opportunities and the means to formulate applicable and relevant moral codes that can be utilised in a secular society. However, the ethical codes provided by natural sciences may not contradict the knowledge gained by God's revelation in Scripture and the moral implications of God's revelation in the Word that became flesh. Christian moral conduct can thus draw on creational gifts and biblical revelation but must in the end answer to the distinct values of Christ. The ethics flowing from the incarnate Word is the final yardstick for bio- and ecoethics and on this foundation Christian ethics can contribute to the current debates in the development of suitable bio- and ecoethical concepts.

\section{Introduction}

The emergence of the need for a reformed theological ethical discourse on the relation between faith and science and the challenges of the modern ethics of human rights, ecoethics and bioethics brought the whole idea of natural law into debate. Natural law as a concept became contentious in the 20th century in reformed theological ethics as a result of the views of Karl Barth and his followers. He blamed the theological notion of natural law as a breeding place for secular ideologies and as giving rise to Nazism and other erroneous theologies. However, Grabill (2006) indicates how this concept is rediscovered in modern-day reformed theological ethics. This presentation revisits the idea of natural law as a possible basis for the development and realisation of Christian moral codes applicable to modern ethical questions, especially bioethics. The central theoretical argument of this contribution is that, due to the general revelation of God in nature, the Spirit of God bestows all humans with creational gifts and seen as such the concept of natural law can be regarded, with certain conditions, as a credible and useful tool in the reformed paradigm. The idea of creational gifts founded in God's revelation in nature can assist Christian ethicists in making plausible contributions to the science and faith, bioethical, human rights and ecoethical discourses. First of all, the development of the concept will be explored with special attention to the view of Calvin and his followers.

\section{Calvin and natural law ${ }^{1}$}

Calvin never wrote a complete and systematic thesis on the concept of natural law (Schreiner 1991:77). These were produced by his followers, such as Vermigli, Zanchi, Turretin and Althusius on the basis of the views of Calvin. Grabill (2006), VanDrunen (2010) and Witte (2007) discuss the views of these authors in detail. The concept ius naturalis or lex naturae read with his views on the principles of the general goodness of God, the doctrine of God's providence, and the rights of individuals are the foundation of Calvin's understanding of civil government and what it entails.

1The author of this article also discusses the ideas of Calvin and Barth regarding natural law in other publications (see Vorster 2014 and the explanation of these authors are repeated here due to the fact that they represent the main streams in the reformed tradition the explanation of these authors are repeated here due to the fact that they represent the main streams in the reformed tradition
regarding natural law and its consequences for social ethics. However, in this article the argument is taken further and is complemented with more recent critique on natural law in an attempt to draw attention to certain limitations to applying the concept in reformed theological ethics. Therefore the concepts of general revelation and creational gifts are introduced to counter the excesses of natural law such as natural theology and natural order or creational order. 
In order to shed some light on his view of the natural law, his perspective on God's common grace as applicable to all people as well as his view on the creation of humankind in the image of God (imago dei) should be explained. According to Calvin, God expressed his common goodness to all people by giving all people the creational gifts such as a moral sense and a religious inclination (semen religiones). He did not use the term creational gifts but the term is a distinct summary of his position. To prove his point he refers to the profane authors and contends that the manner in which they explored the truth proves that they too were recipients of the abundant blessings God extended to depraved humankind (Calvin 1559:2:2:15). All people thus received creational gifts as a result of the common goodness of God (cf. Leith 1989:184).

In addition to this observation Calvin refers to the biblical doctrine of the creation of humankind in the image of God [imago dei]. The fact that humankind was created in the image of God is an affirmation of the remarkable gifts that God bestowed on all people. Arguing from this angle of approach, Calvin draws attention to the basic and inherent dignity of people. Although he does not entertain the term human dignity, he posits that humankind was bequeathed with a special status. People are the most gracious creatures of God's creation and this fact proves the justice, goodness and wisdom of God (Calvin 1559:1:15:1). People reflect the divine glory of God and this reflection is humankind's most remarkable quality. This image is situated in the enlightenment of reason and pureness of heart. Although this image was blemished by the fall, it was not lost or destroyed (Calvin 1559:1:15:4). The image of believers will eventually be fully restored but this restoration can only be realised by the second Adam, namely Christ. All people are able to comprehend God through God's revelation in creation and the gospel of redemption.

To understand people's inherent ability to know God, the reader of Calvin should distinguish between his anthropological and soteriological doctrines. As a result of the fall and humankind's depravity, the fallen people lost their free will and their ability to redeem themselves from the bondage of sin. From a soteriological point of view humankind became totally lost and unable to pursue goodness and truth. Calvin (1559:2:1:5) refers to the early Christian authors, such as Augustine, who described this total depravity as original sin. Original sin is according to Calvin (1559:2:1:8), the inherited evil of humankind's nature that encompasses spirit, body and soul. The sin brings people before God in a state of guilt and creates in people the evil deeds called the works of the flesh in Scripture. In spite of the creational gifts to all people, humans became totally depraved and thus unable to secure their own salvation. Humanity's only way to salvation is the free grace of God which is expressed in the reconciliatory sacrifice of Christ, effected by the Holy Spirit and received only through faith and in the spirit of humiliation and repentance (1559:3:1:1).

In spite of this soteriology, Calvin founds his anthropology and ethics in the concept of imago dei. Although humankind's alienation from God as a result of the fall led to a distortion of the imago dei, God's image in people was not destroyed (Calvin 1559:1:15:4). People maintain a dignity and they must abide by the responsibilities flowing from this dignity. In his explanation of the scope of the Christian love Calvin (1559:3:7:6) asserts that God's commandment to love all people and to do good to all people emanates from the fact that God has bestowed a dignity on all people. Believers should always see and respect the image of God in other people. As proof of this point of view he refers to Genesis 1:27. He pleads that people should regard each other as fellow human beings with inherent dignity in the eyes of God.

In his distinction between the spiritual and the civilian kingdoms, Calvin (1559:2:7:1) refers to natural law [lex naturae] as a created moral law that rules over both kingdoms. This moral law is engraved in the conscience, repeated in Scripture and summarised in the Decalogue. To explain this idea the metaphor of concentric circles can be utilised. The outside circle is the natural law engraved in the conscience. The inner circle is the revelation of God in the written Word or Scripture. The core is the Decalogue as it is summarised in various parts of Scripture. Calvin uses many terms to describe the moral law that is engraved in the conscience of humankind. Witte (2007:59) mentions a few: 'the voice of nature', 'the engraved law', 'the law of nature', 'the natural law', 'the inner mind', 'the rule of equity', 'the natural sense', 'the sense of divine judgement', 'the testimony of the heart', 'the inner voice' and others. These terms have also been well described by Bohatec (1934:3 \& 1962:19) and VanDrunen (2010) who provides an extended explanation of these concepts in his recent publication. All these concepts as they are employed by Calvin point to the fact that God has bestowed creational gifts upon all people which entails that non-believers can also realise justice, can make morally sound decisions, and can maintain law and order in society. In this respect he followed the views of the predecessors of the Reformation (McNeil 1965:168). However, Calvin differed from the premise of Aquinas and the Roman Catholic theology of his time which regarded natural law as a totally independent source of the common good that can be exploited by human reason and can function as a moral law apart from God's law.

Calvin (1559:2:7:1) rather regarded the lex naturae as a creational gift to humankind which entails a moral sense. In his introduction to the explanation of the Decalogue he first of all pays attention to this law God has given to all people. In his commentary on Romans 2:14-15 he also maintains that the sense of law and justice is engraved in the hearts of all people (Calvin 1964:48). He entertains the same idea in his sermons on Deuteronomy 4:44-6:4 and 19:14-15.

Every person has a moral sense and an engraved inclination for justice and as such has the responsibility to realise morality and just laws. However, this inclination does not justify the sinner before God. It has a social dimension only and is also an indication of the equality and human dignity of 
all people. The purpose of this creational gift is to maintain a certain level of morality and civil justice in order to prevent creation from collapsing into total disorder.

Although Calvin did not present a comprehensive thesis on natural law, his contemporary Vermigli and his followers Althusius and Turretin developed his ideas and applied them to ethics, politics and law. Turretin (1997:1:3:4) followed in the footsteps of Calvin and gave the following reasons for God's creational gift of natural law. It is given for the following reasons:

- As a testimony of God's goodness to sinners who are entirely unworthy of such a gift. To prove his point of view he refers to Acts 14:16-17 and John 1:5.

- As a foundation for the external discipline necessary to prevent society from becoming absolutely corrupt. In this instance he refers to Romans. 2:14-15.

- As a subjective condition of the human being to enable people to receive the light of grace because God does not appeal to animals but to rational people.

- As an encouragement for people to seek the more enlightened revelation. In this regard he refers to Acts 14:27.

- As a gift that excludes all justification for unbelief and revolt against God and what activates the conscience. In this respect he refers to Romans 1:20; 2:15-16.

Calvin's exposition of the lex naturae and the calling of all people to realise this in a positive law and moral norms had a huge influence on the development of constitutional law. Witte (2007:xi) describes this influence in his research on the development of human rights during early and modern Calvinism. His ideas influenced many and were carried forward in times of constitutional crises by authoritative leaders in France, the Netherlands and America. In this respect the names of Theodore Beza, Johannes Althusius, John Milton, John Winthrop, John Adams and others can be mentioned. In modern times his views resonated in the political thought of Kuyper (1916:5), the reformation philosophy of Bavinck (1908:160) and the philosophy of the idea of law of Dooyeweerd (1936). They modernised Calvin's idea of natural law and applied it to dramatic reforms in the fields of law and politics. This idea among others became a force behind western constitutionalism. The main contribution of Calvin's idea of natural law was his acknowledgement that it was possible for people to derive universal ethical norms for the organisation of civil life and the prevention of chaos due to God's revelation in nature.

\section{Critical voices}

The idea of natural law has periodically emerged from various theological traditions since the Reformation, and these are discussed by Berkhouwer (1951:146ff.). However, the views of Calvin, his contemporaries and followers on natural law met with serious critique in the early 20th century due to among others the criticism of Karl Barth on the concept of natural law and its theological foundation. He voiced his critique on natural law in his well-known debate with Brunner (Brunner \& Barth 1946). Against the idea of Brunner which resonated with the Calvinist position, Barth maintains that theologians must learn to interpret revelation as grace and grace as revelation and must reject the idea of a theologia naturalis. Natural theology leads to all kinds of theological and ideological excesses. He questions the viewpoint of Brunner that humans have a capacity for revelation irrespective of sin. The fact that a human being can remain a responsible being is due to the grace of God and has nothing to do with an intrinsic moral cognition. If, like Calvin, one views the biblical revelation as the lens via which a person can understand the revelation in nature, then it becomes clear that knowledge drawn from nature is inadequate. If it is inadequate, a theologia naturalis is impossible. In Barth's view Brunner contradicts himself when he adheres on the one hand to the sola Scriptura but on the other hand acknowledges a capacity for revelation in nature as a source of knowledge of God and his works (Brunner \& Barth 1946:81).

Barth also criticises Brunner's idea of an innate natural moral cognition resting in the providence of God. He maintains that providence is not a separate and independent deed of God, but it is inherently combined with prophecy and fulfilment, law and gospel, the covenant and the Messiah, the children of God and their subsequent redemption (Brunner \& Barth 1946:84). Providence is in his view part and parcel of the revelation of God in Christ and serves the purpose to show unbelievers the gospel and to call them to conversion and faith. Providence can thus not be seen as a special gift of God to all people which enables them to distinguish between good and evil. To him proponents of the idea of an innate natural law find themselves in the sphere of Roman Catholicism, Anabaptism and Pietism where the idea that God bestows a special grace to all people is prominent. To what will such a theological presupposition lead? It is clear that Barth feared that the idea of a natural theology, resting in the acceptance of the notion of the lex naturae, could lead to a romanticism and eventual idolisation of secular ideologies a phenomenon he experienced in his own lifetime with the emergence of National Socialism. The same happened in South Africa with the emergence of the Apartheid theology and its severe political consequences. These developments make his view worth considering on the basis of the possibility of natural theology.

Furthermore Barth questioned Brunner's explanation of creational orders that determine social life and regulate society. Among these Brunner refers to marriage and the state marriage in its pre-fall condition and the state in its post-fall condition. He explains that a believer in Christ will understand creational order better than an unbeliever and that a believing person can derive principles from the creational order that can determine social life. Society is subjected to the authority of state - the result of a creational order. In his response Barth asks what standards human beings should use to identify a creational order and to distinguish between 'higher' and 'lower' creational orders 
(Brunner \& Barth 1946:86). Will it be instinct or reason? The acknowledgement of instinct or reason as a means by which to differentiate between creational orders and to attach a certain amount of authority to them runs against the doctrine of the total depravity of humankind and this idea creates a new ideology which contradicts reformed theology. Knowledge cannot be derived from natural law or creational order, because all knowledge is founded in the revelation of God in Christ. Only the Word of God in Scripture can be the message of the church in the world. This message is that human beings can do nothing to work their own salvation or to live socially in an orderly fashion. All knowledge is founded in the sola gratia and the church should be free from all bondages that flow from the values of the so-called creational orders.

Barth reacted very strongly to Brunner's statement that a human being can, as a result of the imago dei, develop a formal capacity to understand the general revelation of God in nature and that this general revelation should be regarded as the formal 'point of contact' in the process of understanding the revelation in Christ and in Scripture (Brunner \& Barth 1946:89). In his view Brunner justifies a kind of innate justification of all people which enables them to understand the gospel without the enlightenment of the Spirit based on God's revelation in Christ. Any innate capacity for understanding revelation contradicts the biblical message of the total depravity of humankind. The confession of the total depravity of humankind, the redemption in Christ, the sola Scriptura and the sola gratia refutes any form of an innate knowledge of God and any capacity of understanding the revelation of God based on natural law. Barth defines Brunner's view as 'Thomistic' and 'Neo-Protestantism'. In the light of biblical texts such as 1 Corinthians 2:10 and Galatians 2:20 Barth argues that the life of humans in Christ by the Spirit precedes any point of contact between God and the corrupt humankind. People must be regenerated and come to faith first before they can attain and understand any knowledge of God. Knowledge of God cannot spring from the heart that is not born again but can only be reached via the enlightenment of the Spirit. Firstly the enlightenment by the Spirit and then the knowledge of God (Brunner \& Barth 1946:92). Barth then says that it is impossible to reconcile evangelical theology with natural theology as Brunner does, according to him. And where this is done natural theology will eventually get preference. A reintroduction of natural theology will also require a new pneumatology. The theological thinking of Brunner in this regard will lead people astray from the foundations of evangelical theology (Brunner \& Barth 1946:94).

In his explanation of Calvin's view of the lex naturae Barth accuses Brunner of misrepresenting the view of Calvin (Brunner \& Barth 1946:95). In his opinion the creation narrative did not lead Calvin to search for another source of the revelation of God other than the revelation in Scripture. Calvin's anthropology was founded in Scripture and not in a philosophy of history or in nature. However, in a vague argument he concedes that Calvin acknowledged that knowledge of God through revelation in nature is a possibility but that Calvin did not state this as a fact, because between the objective possibility and the subjective possibility lies the fall. Due to the fall humans became blind to revelation; not because revelation is unclear but because they lost the ability to comprehend the revelation of God. He also says that Brunner misrepresents the view of Roman Catholicism as it is developed by Thomas Aquinas. In his opinion the Roman Catholic view also acknowledges the preparatory grace of God that enables humans to acquire knowledge of God. The preparatory grace precedes all knowledge of God. He affirms again that true theologia naturalis can exist only where the eyes of human beings are opened by Christ and such a theology must be developed from Scripture and Scripture alone. Creational orders are also obscured by sin and must be made recognisable by Christ through the enlightenment of the Spirit of God. According to Barth this is the view of Calvin. He regards Brunner's view as a deviation from Calvin and more in line with Turretin (1997:105). As explained earlier in this article Turretin was known for his use of the lex naturae in the foundation of law and jurisprudence.

Is Barth's understanding of Calvin's interpretation of the lex naturae correct? As explained in the elucidation of Calvin's various references to the idea of natural law in different terms and concepts, it is fair to conclude that Calvin acknowledged the moral capacity of all people irrespective of sin. He used the concept of natural law to explain that the Spirit of God bestowed upon all people a moral conscience enabling them to prevent the total collapse of the moral order. This author supports the idea of creational gifts to all people, allowing them to grasp the difference between right and wrong. This notion also serves to explain the historic fact that people who were never confronted with the gospel of Christ are still able to develop noble moral principles such as the protection of life, creation, and the property of others.

Barth thus deviated from the premise of lex naturae and had a huge influence on 20th-century reformed theological ethics in this regard. In his well-known debate with Brunner he pleads for a deviation from any form of natural theology because it is a theology of compromise and is responsible for some of the secular theologies of his time, for example the Nazi-theology of the Reichskirche in the 1930s. In his view all knowledge is founded in the revelation of God in Jesus Christ. Against the background of the development of political theologies, Barth's criticism of natural law led to a general sense of suspicion against it in reformed circles. The interest in the concept of natural law in reformation philosophy and theology receded in the later 20th century due to the influence of other scholars such as Berkhouwer and Van Til (Grabill 2006:6 \& 190). However, both Grabill (2006) and VanDrunen (2010) are convinced that the idea as it was developed and applied by Calvin and his adherents, receives new positive assessment today and paves the way for the development of moral codes and constitutional ideas in reformational thinking that can contribute to modern-day ethical and political discourses. Nonetheless Barth's criticism 
of a definition of natural law that can lead to the development of a natural theology is valid and further discourse on the matter should heed his warning against secularism.

In such a discourse the recent presentation of Welker (2014), a prominent modern-day scholar in reformation theology, should also be considered. Welker (2014) voiced a similar critique against natural law as is the case with Barth. He (Welker 2014) discerns:

difficulties that 'natural law' has in positing normative interconnections between God's justice and righteousness, the observable order in nature and cosmos, and political, legal, and moral efforts to establish salutary relationships and order amongst humans. (p. 1)

\section{He (Welker 2014) voices his critique against:}

efforts made over the course of Western cultural history to ascertain normative correlations between divine legislation, the regularities and order inherent in cosmos and nature and the numerous political, legal and moral attempts to establish relationships and order among humans. (p. 2)

Welker's point of departure is the righteousness of God which is intended for humanity itself. The bestowal of divine righteousness should prompt humans to be grateful to God and to practice justice and righteousness with one another. All righteousness comes from God and there can be no other source of the moral good. Nature cannot serve as a source of the moral law because nature itself is flawed. He asks the question:

How can we speak about the justice and righteousness of God, the creation of all things, if at the same time we see that the world in which we live is utterly permeated by sequential hierarchies of nourishment? (Welker 2014:3)

Any attempt to equate God and nature is naïve and carelessly considered. Welker refers to the priestly account of the story of creation and is of the opinion that this account favours this understanding. On the one hand God calls the work of creation good and even very good but on the other hand creatures are given considerable independent power and thereby also the capability of potentially endangering themselves as well as other creatures. Natural life can only live at the cost of other life. Creatures have to destroy each other in order to exist and even the sun and stars have positive as well as negative functions. The sun warms, but it also burns. 'The dominum terrae in Gen. 1:27-28 regulates conflicts of interest between humans and animals and is associated with the explicit determination of hierarchies in the chain of nourishment' (Welker 2014:4). While myths of antiquity (as well as many modern-day tribal religions JMV) divinise heaven and earth and heavenly bodies, biblical thinking demythologises this view and respects the ambivalent independent power enjoyed by creatures.

Natural law as the knowledge of things divine and human can never be the basis for understanding and grasping God's justice and righteousness. Nor can justice and righteousness in the science of just and unjust (law) be associated with natural law. Natural law cannot offer the principles of justice and righteousness that is necessary to order human relations and jurisprudence in a state. In modernity the emphasis on natural law leads to the increased romanticising of the human spirit and human conscience to such an extent that it is said that natural law resides in the human spirit itself. Welker (2014) states:

What ultimately emerges is that, on the one hand, conscience and positive law are emancipated from religion, and, on the other hand, that conscience is the inner judge, often in the name of God, is polarized over against professional judges in the name of society. (p. 5)

In this way God's righteousness and justice are secularised. In his seminal work on Christology, Welker (2012:44) describes the self-secularisation of the neo-Protestant faith due to its new-found dependence on natural knowledge and the light of reason. In his 2014 presentation he refers to the famous dialogue between Cardinal Ratzinger and Habermas where the Cardinal on the one hand lauded the idea of natural law as the basis for dialogue between Christians and secular society but on the other hand had to admit that the instrument became 'blunt' due to the rise of evolutionary science which entails that the victory of the view of evolution has meant the end of this view of nature. Welker himself concludes in this regard that the theory of natural law is insignificant due to its deficient systematic tenability rather than the victory of the theory of evolution as the Cardinal posits.

He asks whether there is an efficacious power in the midst of the ambivalent disposition and organisation of natural real life. Many religious traditions have viewed this power as God's law and divine Spirit, but asks what then is the law, because various traditions have different views on what God's law is all about. He refers to Matthew 23:23 and concludes that the 'weightier matters of the law' involve the interrelation between justice and mercy and faith. Here we encounter a systematic fundamental structure of the law. Welker (2014) argues:

The differentiated union of justice and mercy, or of righteousness and systematic protection of the weak, is of key importance for discerning God's justice and righteousness and their normative and liberating potential, for here the law establishes a value system that in fact runs counter to the natural tendency of life, namely, counter to the tendency to preserve oneself at the cost of other life. (p. 8)

In this sense the law demands self-withdrawal on behalf of the others which is totally opposite to the natural inclination of exploitation. The doctrine of God's justice, righteousness and mercy focuses on a paradox that is also accessible to nonreligious thinking. All human actions of love, caring, selfwithdrawal and of accommodation are the results of God's righteousness and mercy expressed in his law given to people. This is a force bigger than nature and distinguishes human beings in a special way. The natural will fade away, but humans are made 'a little lower than God' (Ps 8:6), and it is through the divine spirit that gifts of mercy are bestowed upon them. 
The divine spirit should not be identified with intellect and reason because it is poured out over people and liberates the weak from the autocracies of life. In a predatory nature with all its deficiencies, the counterforces of violence and destruction are at work: forces of compassion, mercy and love, and forces that accompany the search for truth and justice. These forces direct human life beyond the natural inclination of selfpreservation. God's spirit inspires the human spirit and God's justice and righteousness can be taken as the constant touchstone for assessing political and religious dynamics of power and rule. Guided by God's spirit, humans can love, forgive, and promote freedom and peace. This power is neither driven nor guided by nature and cannot be grasped by the concept of natural law. In this regard Welker (2014) states:

It is instead a free, creative mode of behaviour and action that elevates finite, moral existence that otherwise seems condemned to ultimate futility. In religious and spiritual contexts, this power is identified as God's justice and righteousness. (p. 12)

This righteousness acquires clear contours in Jesus Christ and becomes the model for Christian witness and charitable acts. God's righteousness is a gift of God with which he heals and uplifts human beings. All morals come from God and cannot be ascribed to natural law or reason.

Welker's angle of approach is indeed refreshing and should be considered in the new debate in reformed circles about natural law - especially his emphasis on the effect of sin and the guiding work of the Spirit in the moral endeavours of the human spirit. The following section is an attempt to identify a way forward with particular reference to bioethical decisionmaking.

\section{A way forward}

The critique of Barth, Welker and others such as Douma (1973) is indeed valid and should be considered because they warn against the introduction of a mere humanist and secularist ethics with the human mind at the centre. However, while acknowledging that all morals come from God, the idea of an 'engraved law' in the hearts of human beings should not be abolished. How should one explain the high moral standards held by African cultural and religious traditions long before these civilisations had had any contact with Christianity? VanDrunen (2014:1) poses a valid question when he asks how we should understand the existence of universal human rights and how we can explain to people today that they are accountable to God and fall under his just judgement. I would start the discussion on a way forward by first stating how the natural law should not be defined - in view of the critique of Barth, Welker and Berkhouwer (1951:146ff.). Natural law is not a separate, independent, and inherent quality of humankind. It does not grow out of the human spirit and enables humans to find the good and the moral in their own minds. It is not a source of knowledge beyond the revelation of God. It does not provide a secular ethic that runs alongside or even against the morality given by God. It cannot exist in a moral law that can be exploited by the light of reason in the Kantian sense. Therefore the influence of sin and evil and the depravity of humankind and nature are too obvious, as Barth and Welker explain.

A valuable starting point in considering a way forward is the doctrine of the revelation of God as was developed in the Dutch Reformed theology since Bavinck. Bavinck (1908) delivered his Stone Lectures at Princeton in 1908 and published these lectures under the topic Wijsbegeerte der openbaring [The Philosophy of Revelation]. This publication, along with his 4-volume publication of Gereformeerde dogmatiek [Reformed Dogmatics], has guided the Dutch Reformed thinking in this regard since the early 20th century (see also Bavinck 1928:225) and influenced systematic theologians in this tradition since then. On this topic the works of Berkhof (1958 - reprinted 16 times until 2003; 1986), Berkhouwer (1951), Grudem (1994:149), Heyns 1978; Polman (s.a:144) and Van Genderen and Velema (1992) can also be mentioned. Bavinck's views are currently revisited by Grabill (2006), Witte (2007) and VanDrunen (2010 \& 2014).

Bavinck (1908:70) grounds his theology in the fact that God can be known only because he makes himself known by revealing himself to humans. Against the rationalism and supranaturalism of his time Bavinck distinguished between God's general and his particular revelation. The general revelation is the revelation in creation (nature and history) and the special revelation is the revelation in the Scripture as the written Word of God. Berkhof (1958) summarises this view as follows:

The Bible testifies to a twofold revelation of God: a revelation in nature round about us, in human consciousness, and in the providential government of the world; and a revelation embodied in the Bible as the Word of God. (p. 36)

All sciences study the revelation of God. God's works can be studied by natural science and philosophy and his Word can be studied by theology. However, general and particular revelation work in concert and should not be seen as separate sources of knowledge as is done by rationalism and supranaturalism. Bavinck's view regarding revelation was accepted but also criticised by his followers and the term general and particular revelation became obsolete in this tradition. The main point of critique was that such a distinction does exactly what Bavinck warned against - it elevates a natural knowledge of God as an independent knowledge apart from the revelation in the Word. However, the emphasis on the twofold revelation founded in God's universal grace and providence as this idea developed in the reformed tradition, is still worth considering if it is defined as one revelation in creation contracted in the Scripture as the written Word and further in the revelation in Christ as the incarnate Word. Berkhouwer (1951:129) stresses this unity in his defence of revelation in creation against the critique of Barth.

The revelation of God can also be described with the metaphor of three concentric circles. The outer circle denotes the revelation of God in creation. Humans can see the work of God in his works and providence. The middle circle points 
to the special revelation of God in his written Word and this revelation can be grasped by people whose eyes have been opened by the Spirit of God. They can see more of God - not only his works in creation and history, but his redemptive work and the renewal of the earth under his reign. And the inner circle indicates his revelation in the incarnate Word Jesus Christ.

God's one revelation moves from the general to the particular and with this the various gifts of his spirit. People receive creational gifts, the gifts that Calvin described as the engraved law. These gifts enable humans to act morally. Welker is thus to the point with his statement that all morals come from God. These gifts are not independent qualities that can be excavated from nature itself or a certain ability of humans themselves - they are gifts bestowed by the Spirit of God. The concept of the revelation of God described by the metaphor of the concentric circles and the creational gifts bestowed by the spirit of God can be used as a foundation to explain the central theoretical argument of this article. On this foundation the following application is proposed.

\section{Application}

The revelation in the book of nature and the creational gifts of God to all humans can be utilised as a source of moral decisionmaking in the field of bioethics and ecoethics where the applicable results of natural sciences can be taken into account. Natural sciences can provide knowledge which can be used in Christian moral decisionmaking regarding issues of life and death and ecological concerns.

The revelation in the written Word is a richer source of moral knowledge provided that a sound hermeneutics is used. Here the emphasis on the biblical historical context, the 'consent of the parts' (Westminster Confession), the unity of the ongoing biblical revelation and revelation history are important to avoid the threat of biblicism and fundamentalism. Moral principles must be formulated against the background of the broad themes in the biblical revelation such as the reign of God, the covenant, death and resurrection, life, love, sin and grace and others.

The revelation in the incarnate Word provides that test brick of all moral decisionmaking. In other words Christian morality can never run against the purpose, meaning and implications of the incarnate Word, Jesus Christ as the living Lord and his reign. The ethics of Christ is the 'great commandment' and 'the golden rule' and implies that human actions may not be destructive or bring about harm and should nurture among others the values of life, harmony and ecosensitivity in human life and the creation. The revelation in the incarnate Word guides Christian ethicists to avoid secular ideologies based on an independent moral law and the reign of human reason in ethical reasoning.

When utilising the metaphor of the concentric circles, the following statement can be made: Natural knowledge based on God's revelation in creation and his creational gifts as these are revealed by among others natural sciences, provides
Christian ethics offers opportunities and the means to formulate applicable and relevant moral codes that can be utilised in the bio- and ecoethical debates of today. However, the application of these principles may not contradict the morality flowing from God's revelation in Scripture and the moral implications of God's revelation in the Word that became flesh. Christian moral conduct can thus draw on creational gifts but must in the end answer to the distinct values of God's revelation in Scripture and in Christ.

\section{Acknowledgements}

This work is based on the research supported by the National Research Foundation (NRF). Any opinion, finding and conclusion or recommendation expressed in this material is that of the author and the NRF does not accept any responsibility in this regard.

\section{Competing interests}

The author declares that he has no financial or personal relationships which may have inappropriately influenced him in writing this article.

\section{References}

Bavinck, H., 1908, Wijsbegeerte der openbaring, Kok, Kampen. Bavinck, H., 1928, Gereformeerde dogmatiek, vol. 1, Kok, Kampen. Berkhof, H., 1986, Christian faith, Eerdmans, Grand Rapids, MI. Berkhof, L., 1958, Systematic theology, The Banner of Truth Trust, Edinburgh. Berkhouwer, G.C., 1951, De algemene openbaring, Kok, Kampen. Bohatec, J., 1934, Calvin und das Recht, Bolhaus, Vienna.

Bohatec, J., 1962, Calvins lehre von Staat und Kirche, mit besonderer Berucksichtigung des Organismus gedankens, Scientia Aalen, Breslau.

Brunner, E. \& Barth, K., 1946, Natural theology, Geofgrey Bless, London.

Calvin, J., 1964, Commentary upon the epistle of Saint Paul to the Romans, Calvin Translation Society, Edinburgh.

Calvin, J., 2008 [1559], Institutes of the Christian religion, Hendriksen, Peabody, MA. Dooyeweerd, H., 1936, De wijsbegeerte der wetsidee, Deel 3, Paris.

Douma, J., 1973, Natuurrecht - Een betrouwbaar gids? Vuurbraak, Groningen.

Grabill, S.J., 2006, Rediscovering the natural law in reformed theological ethics, Eerdmans, Grand Rapids, MI.

Grudem, W., 1994, Systematic theology: An introduction to biblical doctrine, Zondervan, Grand Rapids, MI.

Heyns, J.A., 1978, Dogmatiek, N.G. Kerkboekhandel, Pretoria.

Kuyper, A., 1916, Antirevolutionaire Staatkunde, Kok, Kampen

Leith, J.H., 1989, John Calvin's doctrine of the Christian life, Westminster, Louisville, KY.

McNeil, J.T., 1965, 'John Calvin and civil government', in G.L. Hunt (ed.), Calvinism and the political order, Westminster, Philadelphia, PA.

Polman, A.D.R., s.a., Onze Nederlandse Geloofsbelijdenis: Verklaard uit het verleden geconfronteerd met het heden, Wever, Franeker.

Schreiner, S.E., 1991, The theatre of his glory: Nature and natural order in the thought of John Calvin, Baker Book House, Grand Rapids, MI.

Turretin, F., 1997, Institutes of elenctic theology, vol. 1, vert. G.M. Geiger, T \& T Publishing, Phillipsburg, NJ.

Van Genderen, J. \& Velema, W.H., 1992, Beknopte gereformeerde dogmatiek, Kok, Kampen.

VanDrunen, D. 2010, Natural law and the two kingdoms: A study in the development of reformed social thought, Eerdmans, Grand Rapids, MI.

VanDrunen, D., 2014, Divine covenants and moral order: A biblical theology of natural law, Eerdmans, Grand Rapids, MI.

Vorster, J.M., 2014, Christelike etiek in 'n sekulariserende samelewing, AOSIS e-books, Cape Town, viewed n.d., from http://www.dx.doi.org/10.4102/aosis.ceiss.2014.01 Welker, M., 2012, God the revealed: Christology, Eerdmans, Grand Rapids, MI.

Welker, M., 2014, 'God's justice and righteousness', unpublished lecture delivered on 21 May, in the Old Auditorium of Heidelberg University, Germany. (Copy in possess of the author).

Witte, J., 2007, The reformation of rights: Law, religion, and human rights in early modern Calvinism, Cambridge University Press, Cambridge. 